\title{
The Effects of Using Ceramic Waste Powder and Palm Fiber on Mortar properties
}

\author{
$A L-A Z H A R$ ZAHIR \\ MOHAMMED AL-RUQAISHI \\ Omar R. Khaleel
}

\author{
MIDDLE EAST COLLEGE \\ Middle East College
}

\begin{abstract}
There are multiple industries that generate ceramic in the world. The ceramic waste ends as a landfill; and there is no it's recycle. Moreover, palm fibers can be used for various purposes such as it can be mixed with mortar in order to minimize cracks. The objective of this study was to investigate the effects of using ceramic waste powder and palm fiber on properties of mortar. OPC is partially replaced with ceramic waste powder with different percentages such as $10 \%, 20 \%$, and $30 \%$ and palm fiber is added with $10 \%$ of replacement only at $0.5 \%, 1 \%$ and $1.5 \%$ of the weight of cement. The specimens are compared with the reference mix in the water absorption test under $105 \mathrm{c}^{\circ}$ for $24 / \mathrm{h}$ and compressive strength test after 7 and 14 days. The results showed that the optimum percentage of cement replacement with ceramic powder was $10 \%$. Regarding the fiber, the percentage of water absorption got increased while increasing the fiber. The compressive strength of mortar with fiber was obtained more than the normal. More percentage of fiber led to more strength of mortar.
\end{abstract}

\section{Introduction}

Mortar refers to the mixture which consists of cement, fine aggregate, and water. Mortar has a significant impact on construction industry that acts as bonding element which holds bricks, stones, and masonry units together in the building and structure (Dhir.R.K et.al, (2017). There are various types of mortar which are used for different purposes. Cement mortar is used as fine aggregate and as binding material that adds on strength. Lime mortar is used as sand and binding material. Gauged mortar is a lime mortar but cement is added to gain more strength. Surki mortar is economic and is used as a fine aggregate and binding material. Mud mortar is used as sawdust, fine aggregate, and binding material. It is also useful when cement or lime are not available (Civil Engineering 2019).

There are various industries that generate ceramic around the world. Therefore, $20 \%$ to $30 \%$ waste is produced from the total ceramic production (Ceramic World 2017). The waste of ceramic ends to be as a landfill and there is no recycle. The maximum amount of cement like OPC can partially be replaced with ceramic waste powder in the concrete. It woud effect positively to the environment by reducing amount of landfill. For instance, the benefits could be such as reducing the consumption of resources, using less energy, minimizing $\mathrm{CO}_{2}$ emission and others harmful gases, and also reducing the negative impact for the environment (D.Raval, A., N.Patel, Dr.I., and Pitroda, Prof.J. 2013).

Palm fiber means a fiber leaf that can be obtained from leaves of dwarf palm. There are various types of palm fiber trees such as oil, bamboo, coir, and date palm fiber. Each type of palm fiber contains different properties and several places can be sued based on purpose (TIS 2019).

The work has been done by using the lab tests such as water absorption and compressive strength tests. Water absorption test refers to the determination of the water amount that absorbed in a specified condition. There are various factors that affect water absorption such as temperature (Intertek 2019) and percentage is obtained from weight of specimen wet subtracted from dry and divided by weight of dry multiply 100 . Compressive strength means the ability of materials to resist 
of breaking under the compression. The formula that can be used to obtain the compressive strength is that maximum applied load divide by area of surface loaded $\sigma=\mathrm{P} / \mathrm{A}$ in MPa or N/mm ${ }^{2}$ unit (Broughton.W 2014).

The plan of this report is that to obtain the properties of the mortar when using ceramic waste powder as partially replacement of cement. The palm fiber will be added to the optimum percentage of cement replacement which is $10 \%$. Firstly, casting mortar cubs is made with normal mix, then, cement is replaced with ceramic waste at $10 \%, 20 \%$, and $30 \%$. Palm fiber is added to $10 \%$ of cement replacement $0.5 \%, 1 \%$, and $1.5 \%$. Secondly, cubs are cured in the water after one day of casting, two specimens from each mix are measured for the weight before and after they are put in oven for $24 \backslash \mathrm{h}$ under $105 \mathrm{c}^{\circ}$ to obtain water absorption. Regarding the compressive strength, specimens are tasted after 7 and 14 days of curing in the water. Finally, the result of both water absorption and compressive strength are compared with previous studies and discussed.

- To investigate the effect of using ceramic waste powder and palm fiber on properties of mortar.

\section{Methodology:}

\section{Materials used:}

\section{Sand:}

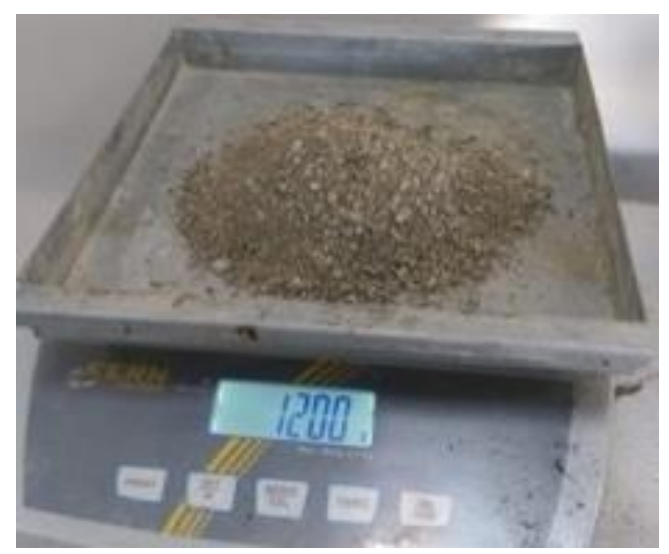

Figure 1. Sand

Fine aggregate is used from zone 2 of normal sand of sand grade and the size is less than $4.75 \mathrm{~mm}$.

\section{Cement:}

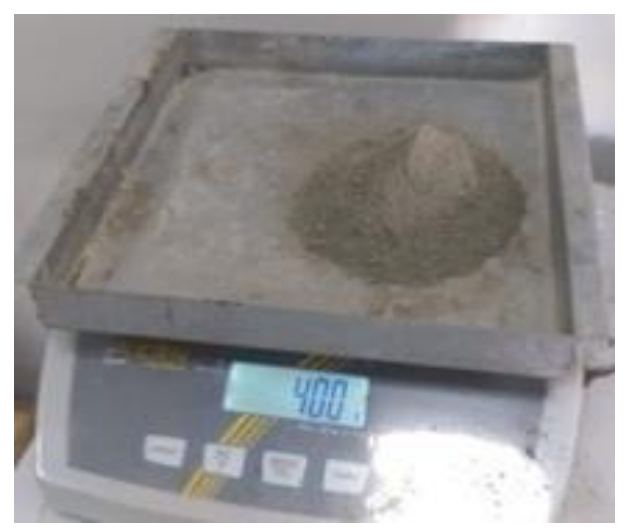




\section{Journal of Student Research}

Figure 2. Cement

The cement used is Ordinary Portland Cement (OPC) and 53 is the grade of cement.

\section{Ceramic Waste Powder;}

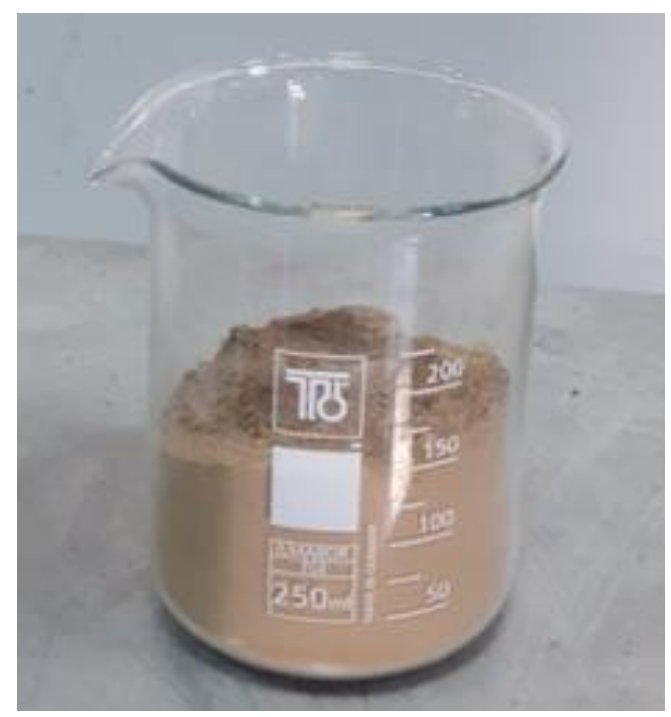

Figure 3. Ceramic waste powder

Tile ceramic is used that is mashed by grinder machine to be powder and the size is less than $4.75 \mathrm{~mm}$.

\section{Palm Fiber:}

Figure 4. Palm fiber

Palm fiber that is used from date palm tree and is cut to small size $10 \mathrm{~cm}$.

\section{Water:}

A portable water is used on the investigation.

\section{Instrument used:}

\section{Figure 5.}

\section{Mix Process:}

- Firstly, we prepared the equipment and materials. $1200 \mathrm{~g}$ sand, $400 \mathrm{~g}$ cement, $200 \mathrm{ml}$ water, ceramic and fiber.

- Cement was mixed with sand then we added water gradually.

- Oil was put on cubes; then they were cast in three layers and compacted 25 times in each layer. 
- At $10 \%, 20 \%$, and $30 \%$ of cement replacement, cement and ceramic were mixed together first, then with sand, after that the water was added.

- $0.5 \%, 1 \%$, and $1.5 \%$ of fiber were added to $10 \%$ of cement replacement that mixed with cement and ceramic first then with sand after that added the water.

- After one day of casting, specimens were cured in water.

- Water absorption was tested after $24 / \mathrm{h}$ of curing, and compressive strength was tested after 7 and 14 days.

\section{Experiments:}

\section{Water Absorption:}

The objective of the water absorption test was to determine the water absorption of mater. After the specimens were cured for $24 / \mathrm{h}$, they were taken out of the curing tank and the water was swabbed by using tissue. After that, the weight of specimens was measured and then put in the oven under $105 \mathrm{c}^{\circ}$ for $24 / \mathrm{h}$. The specimens were taken out from oven and measured the weight again. Finally, water absorption was calculated.

\section{Compressive Strength:}

The objective of the compressive strength test was to evaluate the strength of mortar cubes. Based on the British Standard, the dimension of cubes was $50 \mathrm{~cm}$ x $50 \mathrm{~cm} \times 50 \mathrm{~cm}$. The cubes were taken out of curing tank and swabbed in the water using tissue. The specimens were rotated to $90^{\circ}$. Then, they were put inside the machine and the load was applied. Results were obtained later.

\section{Results Analysis}

\section{Water Absorption Test:}

\begin{tabular}{|c|c|c|c|c|c|c|c|}
\hline \multicolumn{8}{|c|}{ Cement Replacement with Ceramic and Adding Fiber $(\mathrm{F})$ with Optimum Percentage } \\
\hline \multirow{4}{*}{$\begin{array}{l}\text { Weight of } \\
\text { specimens } \\
\text { before put on } \\
\text { oven }\end{array}$} & $0 \% \mathrm{~g}$ & $10 \% \mathrm{~g}$ & $20 \% \mathrm{~g}$ & $30 \% \mathrm{~g}$ & $10 \%+0.5 \mathrm{~F} \mathrm{~g}$ & $10 \%+1 \mathrm{~F} \mathrm{~g}$ & $10 \%+1.5 \mathrm{~F} \mathrm{~g}$ \\
\hline & 292 & 286 & 289 & 287 & 284 & 283 & 289 \\
\hline & 307 & 288 & 279 & 282 & 286 & 285 & 302 \\
\hline & $\mathrm{S}=299.5$ & 287 & 284 & 284.5 & 285 & 184 & 295.5 \\
\hline \multirow{3}{*}{$\begin{array}{l}\text { Weight of } \\
\text { specimens } \\
\text { after put on } \\
\text { oven }\end{array}$} & 268 & 262 & 263 & 271 & 260 & 256 & 265 \\
\hline & 285 & 270 & 267 & 260 & 263 & 258 & 268 \\
\hline & $S=276.5$ & 266 & 256 & 265.5 & 261.5 & 257 & 266.5 \\
\hline
\end{tabular}

Table 1. Water absorption results

\section{Compressive Strength Test:}

\begin{tabular}{|l|l|l|l|l|l|l|}
\hline \multicolumn{7}{|c|}{ Cement Replacement with Ceramic and Adding Fiber (F) with Optimum Percentage } \\
\hline $0 \% \mathrm{MPa}$ & $10 \% \mathrm{MPa}$ & $20 \% \mathrm{MPa}$ & $30 \% \mathrm{MPa}$ & $\begin{array}{l}10 \%+0.5 \mathrm{~F} \\
\mathrm{MPa}\end{array}$ & $10 \%+1 \mathrm{~F} \mathrm{MPa}$ & $\begin{array}{c}10 \%+1.5 \mathrm{~F} \\
\mathrm{MPa}\end{array}$ \\
\hline 21.65 & 20.7 & 16.8 & 15.5 & 22.98 & 24.7 & 26.6 \\
\hline 22.1 & 18.9 & 16.3 & 14.9 & 23.8 & 25.4 & 27.9 \\
\hline 21.3 & 19.7 & 15.9 & 14.4 & 22.6 & 25.2 & 25.8 \\
\hline $\mathrm{S}=21.68$ & 19.77 & 16.33 & 14.9 & 23.12 & 25.1 & 26.77 \\
\hline
\end{tabular}

Table 2. Compressive Strength Result after 7 Days 
Journal of Student Research

Fourth Middle East College Student Research Conference, Muscat, Sultanate of Oman

\begin{tabular}{|l|l|l|l|l|l|l|}
\hline \multicolumn{7}{|c|}{ Cement Replacement with Ceramic and Adding Fiber (F) with Optimum Percentage } \\
\hline $0 \% \mathrm{MPa}$ & $10 \% \mathrm{MPa}$ & $20 \% \mathrm{MPa}$ & $30 \% \mathrm{MPa}$ & $\begin{array}{c}10 \%+0.5 \mathrm{~F} \\
\mathrm{MPa}\end{array}$ & $10 \%+1 \mathrm{~F} \mathrm{MPa}$ & $\begin{array}{c}10 \%+1.5 \mathrm{~F} \\
\mathrm{MPa}\end{array}$ \\
\hline 23.5 & 20.8 & 19.7 & 17.9 & 25.9 & 32.6 & 34.7 \\
\hline 24.7 & 21.4 & 19.6 & 16.5 & 26.9 & 31.3 & 34.6 \\
\hline 23.3 & 22.1 & 20 & 18.2 & 27.3 & 33.1 & 35.3 \\
\hline $\mathrm{S}=23.8$ & 21.4 & 19.77 & 17.5 & 26.7 & 32.33 & 35.87 \\
\hline
\end{tabular}

Table 3. Compressive Strength Result after 14 Days

Figure 6.

\section{Result Discussion}

\section{Water Absorption Test:}

Figure 11 illustrates the percentage of water absorption results after $24 / \mathrm{h}$. Overall, the percentage of water absorption is fluctuated, as $20 \%$ of cement replacement with ceramic waste powder is the highest percentage of water absorption that reached more than $10 \%$ due to more porous between particles of sand and ceramic powder. This agrees with the previous study (Tribulova.T and Kotlik.P 2012) that the result of water absorption is more that $10 \%$ due to more porous between sand particles as it shown in figure 12. Regarding the fiber, it shows that the more amount of fiber is added to the mortar mixer the more percentage of water absorption.

\section{Compressive Strength Test;}

Figure 13 illustrates the compressive strength of mortar after 7 and 14 days. Overall, the compressive strength of the reference mix is obtained as $21.68 \mathrm{MPa}$, but the more amount of cement is replaced with ceramic powder the maximum compressive strength is declined. Therefore, the optimum percentage of cement replacement is obtained as $10 \%$ due to the compressive strength is very close to the normal mix, which is $19.77 \mathrm{MPa}$. This agrees with the previous study (Lima.P.R, and Filho.R. 2014) that the compressive strength is decreased when the size of sand is changed as it shown in the figure 14. M1 is the reference mix which uses the size of sand $4.8 \mathrm{~mm}$ but, M2 the size of sand is $0.6 \mathrm{~mm}$. The compressive strength of M1 is more than M2 by almost double. However, the compressive strength of mortar is increased while adding more percentage of fiber as the maximum compressive strength is nearly to reach $35 \mathrm{MPa}$ when fiber is $1.5 \%$.

\section{Conclusion}

Based on the experiment to investigate the effect of using ceramic waste powder and palm fiber on properties of mortar the conclusion is obtained as follow:

1. The highest percentage of water absorption is at $20 \%$ of cement replacement with the ceramic waste powder.

2. While adding more percentage of fiber, the percentage of water absorption is increased.

3. The compressive strength is decreased while increasing the percentage of cement replacement with the ceramic waste powder.

4. The compressive strength is increased while increasing the percentage of fiber.

5. The optimum percentage of cement replacement with ceramic waste powder is $10 \%$.

6 . Fiber has negative impact with water absorption, but effects positively to the compressive strength. 


\section{Journal of Student Research}

Fourth Middle East College Student Research Conference, Muscat, Sultanate of Oman

7. The compressive strength of mortar with fiber is obtained more than the normal.

8. More percentage of fiber leads to more strength of mortar.

\section{References}

Civil Engineering (2019) Types of Mortar [online] available from $<$ https://civiltoday.com/civilengineering-materials/mortar/65-types-of-mortar > [7 May 2019]

Dhir.R.K, Brito.J, Lynn.C, and Silva.R. (2017) 'Concrete Related Applications'. Sustainable Construction Materials 2 (6), 139-195

Broughton.W (2014) 'Testing the mechanical, thermal and chemical properties of adhesives for marine environments'. Adhesives in Marine Engineering 1 (2), 99-154

Intertek (2019) Water Absorption ASTM D570 [online] available from < http://www.intertek.com/polymers/testlopedia/water-absorption-astm-d570/ > [7 May 2019]

Transport Information Service (TIS) (2019) Palm Fiber [online] available from < http://www.tisgdv.de/tis e/ware/fasern/palmfase/palmfase.htm > [7 May 2019]

D.Raval, A., N.Patel, Dr.I., and Pitroda, Prof.J. (2013) 'Ceramic Waste: Effective Replacement Of Cement For Establishing Sustainable Concrete'. International Journal of Engineering Trends and Technology (IJETI) 4 (6), 2231-5381

Ceramic World (2017) World Production and Consumption of Ceramic Tiles [online] available from $<$

https://www.ceramicworldweb.it/cww-en/statistics-and-markets/world-production-and-consumptionof-ceramic-tiles-4/ > [8 May 2019]

Tribulova.T and Kotlik.P (2012) 'PREPARATION OF MORTARS FOR RESTORATION OF ARCHITECTURAL MONUMENTS'. Department of Chemical Technology of Monument Conservation $5(2), 166-280$

Lima.P.R, and Filho.R. (2014) 'compressive Stress-strain Behavior of Cement Mortar-composites Reinforced with Short Sisal Fibre'. Civil Engineering Department17 (1), 38-46 